\title{
A ontologia de Lukács e a sexualidade em perspectiva emancipatória
}

Aurélio Bona Júnior

Doutorando em Educação pela UNICAMP

\section{Resumo}

O presente estudo parte da compreensão de que a sexualidade é uma dimensão de grande importância na constituição educacional da personalidade e na emancipação humana, e visa levantar possibilidades de compreendê-la a partir do pensamento ontológico de György Lukács. Para tal, apresenta e articula os conceitos de ontologia, ser social e trabalho, discute o lugar da subjetividade no ser social, e propõe uma reflexão sobre a sexualidade como dimensão que, mesmo originária de uma pré-disposição biológica, se reveste de sentido social e se faz central no processo de constituição da sociedade.

Palavras-chave: Educação da Sexualidade; Ontologia do ser social; subjetividade.

\begin{abstract}
This study is based on the understanding that sexuality is a very important dimension in the educational constitution of personality and in human emancipation, and intends to raise possibilities of comprehending it from the point of view of György Lukács' onthological thinking. It therefore introduces and articulates the concepts of ontology, social being and work, discusses the room for subjectivity in the social being, and proposes a reflection about sexuality as a socially meaningful dimension, which is central for the constitution of society, even though originating from a biological predisposition.
\end{abstract}

Keywords: Sexuality education; Ontology of social being; subjectivity. 
$\mathrm{P}$

ensar a educação da sexualidade ${ }^{1}$ numa sociedade como a nossa, em que o consumismo e a busca pelo lucro e pelo poder financeiro imperam, em que o sexo tem sido utilizado como um importante meio de consumo, seja de objetos, produtos e adereços relacionados às vivências sexuais e ao culto ao "corpo perfeito", seja de seres humanos cuja importância tem sido violentamente reduzida à adequação corporal a este consumo, é uma tarefa tão desafiadora quanto necessária.

A educação escolar, se pensada na sua função de formadora de cidadãos nos múltiplos aspectos que envolvem o exercício da cidadania, deve ser um instrumento social que promova a formação integral dos indivíduos, nas dimensões ética, estética e política (NUNES, 2006). Nesse intento, compreende-se que a educação da sexualidade exerce fundamental importância. Um indivíduo consciente do lugar do corpo e da sexualidade na constituição de si e nas relações sociais pode, com mais segurança, atingir a emancipação, conforme será demonstrado no decorrer do texto.

O presente texto resulta de parte de uma pesquisa que visa apresentar fundamentos teóricos e metodológicos para se pensar a sexualidade no processo de construção social da individualidade por meio de uma educação que seja emancipatória. Não pretende, bem porque não seria possível, dar conta de todos os aspectos que envolvem um processo educacional com tal amplitude, mas sim levantar, por ora, possibilidades de se compreender, nessa perspectiva, a sexualidade, a partir do pensamento ontológico de György Lukács (1885 - 1971).

Pensador húngaro do início do séc. XX, Lukács possui uma vasta obra dedicada a recuperar, dentro da tradição marxista, a potencialidade de

\footnotetext{
${ }^{1}$ Há a intenção deliberada de se utilizar a expressão "educação da sexualidade”, recusandose as denominações mais recorrentes na literatura sobre o tema, que são "educação sexual" e "orientação sexual". Tal opção deve-se ao entendimento de que a sexualidade é uma dimensão inalienável do ser humano, que parte da condição sexual - que é biológica - mas a transcende no decorrer da constituição das relações sociais, tornando-se essencial na construção da subjetividade e na formação plena do indivíduo enquanto ser social. Em outras palavras, parte-se do entendimento de que não é função primordial da escola educar ou orientar o sexo dos indivíduos, mas educar, em perspectiva emancipatória, a sexualidade.
} 
entendimento do que é essencialmente humano, apesar das derrotas revolucionárias comunistas que acabaram por se estender também às análises de Marx.

Tentando desvincular o pensamento de Marx e Engels sobre o homem das apropriações feitas, principalmente, pelo Stalinismo, o esforço ontológico $^{2}$ do filósofo se deu também no sentido de mostrar que é falsa a concepção liberal de que "a permanência da ordem capitalista se deve ao fato de ela corresponder a uma pretensa 'essência” humana”, segundo a qual “o homem seria [...] de modo essencial e insuperável, um proprietário privado que se relaciona com os outros pela mediação dos interesses egoístas” (LESSA, 2007, p.13). Assim ele tenta recuperar, da teoria de Marx, a investigação do que é essencialmente humano. Entender isso auxilia sobremaneira a compreensão da sexualidade isenta dos atuais imperativos mercadológicos e consumistas.

Lukács recupera a concepção de sujeito presente na obra de Marx e combate veementemente o irracionalismo, as concepções burguesas que tentam naturalizar e eternizar o capitalismo, bem como o estruturalismo que apregoa a morte do sujeito e do homem como produtor da história. Dessa forma, se mostra um pensador com imensas possibilidades heurísticas para proposições de análises sobre a sexualidade e seu papel na constituição do sujeito, sem cair em pensamentos que, para evidenciar o indivíduo, anulam as relações sociais e, com elas, as determinações históricas que o constituem.

Sua crítica se estendeu também aos próprios marxistas, principalmente ao grupo ligado ao stalinismo, cuja concepção teleológica da história representa, para ele, a negação do lugar dos sujeitos no desenrolar dos acontecimentos, concepção fundamental da teoria marxiana (LUKÁCS, 2010).

\footnotetext{
${ }^{2}$ Ontologia: ramo da metafísica que estuda o "ser”, aquilo que existe (Cf. BLACKBURN, 1997, p. 274).
} 
Na Ontologia do ser social, principal obra tida como referência neste estudo, Lukács tentou elaborar uma introdução a pretensos estudos sobre ética, os quais não chegaram a ser escritos por dois motivos: o que era para ser uma introdução tornou-se um longo tratado ontológico, tomando do autor mais tempo do que o esperado; as doenças e a morte o acometeram antes de realizar seu intento por completo. Nessa obra, procura resgatar aquilo que considerou ser o tema principal do pensamento de Marx: o estudo do autodesenvolvimento da vida material e espiritual da sociedade. Contudo, a crítica e as incompreensões surgidas logo após sua publicação, fizeram Lukács sentir a necessidade de escrever os Prolegômenos à ontologia do ser social, em que sintetiza e esclarece, às pressas - antes de sua morte - os principais pressupostos da obra anterior.

Para levantar possibilidades de se compreender a sexualidade a partir do pensamento ontológico de György Lukács, o presente estudo se divide em três partes: Inicialmente, serão apresentados os conceitos de ontologia, de ser social como o mais alto nível ontológico e de trabalho como meio de constituição desse nível. Num segundo momento, será discutido o lugar da subjetividade no conceito de ser social, considerado uma das principais contribuições do autor ao marxismo. Por fim, será proposta uma reflexão sobre a sexualidade como dimensão que, mesmo originária de uma prédisposição biológica, se reveste de sentido social e se faz central no processo de constituição da sociedade que, segundo o autor, se dá ao mesmo tempo em que recuam as barreiras naturais.

\section{A perspectiva emancipatória da ontologia de Lukács.}

Um indivíduo emancipado é aquele que, segundo Nunes (2003, p.12) demonstra uma "conquista da autonomia cultural, da originalidade estética, da responsabilidade ética, da competência produtiva, do compromisso político e social nascido do amadurecimento educacional”. Uma ontologia emancipatória deve contemplar concepções de existência, de homem, de sociedade e de mundo que propiciem tais conquistas, colocando-as como 
entidades dinâmicas, processuais, dialéticas, interdependentes e partícipes do compromisso e da responsabilidade humana no sentido de transformar homem, sociedade e mundo em benefício de toda a humanidade. Deve conceber o Ser como dinâmico e integrador de todos os entes, e não considerá-lo de forma a-histórica ou isolado em suas partes constitutivas.

De modo geral, a tradição filosófica ocidental tendeu a conceber o Ser como estático e independente da realidade material, na perspectiva ontológica inaugurada por Parmênides ${ }^{3}$. Nessa concepção se alicerça também a tradição platônico-cristã de que o verdadeiro Ser é imaterial e eterno e que o conhecimento do que existe materialmente pode se dar de forma isolada e a-histórica, por obra da razão que conhece. Nessa tradição, tudo o que muda ou se transforma é considerado imperfeito; somente o que é eterno ou espiritual é digno de conhecimento. Assim, tudo o que possui matéria, incluindo-se o corpo, é desconsiderado como objeto de conhecimento, e suas manifestações mais a afastam do que aproximam da compreensão do Ser.

A partir do advento da modernidade, segundo Lukács (2010), a filosofia tem resistido a estudar o Ser. Com o surgimento da ciência e o desprezo às especulações teológico-filosóficas, deu-se ênfase à Teoria do Conhecimento. Para ele, esse ramo da filosofia se mostrou incapaz de compreender os problemas ontológicos das ciências, pois se desenvolveu sob os auspícios da ideologia burguesa.

O autor reconhece iniciativas isoladas de se discutir o Ser a partir da modernidade em filósofos como Husserl, Scheler e Heidegger, mas considera suas abordagens individualistas e a-históricas. Critica Kant e Hegel por não considerarem a realidade concreta como ponto de partida de suas teorias, afastando-se da verdadeira problemática do ser; Aponta Sartre como um pensador próximo do marxismo em suas convicções políticas, mas

\footnotetext{
${ }^{3}$ Parmênides (séc. VI a. C.) defendia que o Ser é "incriado, imperecível, indivisível, perfeito e imóvel” (BLACKBURN, 1997, p.290).
} 
que ontologicamente não superou o individualismo característico de seu existencialismo;

Lukács (2010) considera necessário recuperar a discussão sobre o Ser em tempos de desumanização operada pelo avanço das forças produtivas no modelo capitalista. Se a Idade Média secundarizou o humano em função do divino, e se a Modernidade fez o mesmo em função do lucro e da acumulação de capital, cabe resgatar a essência do que é humano por meio de uma ontologia que situe o homem enquanto ser social. Para ele, "hoje [1920], uma tentativa de realmente reconduzir o pensamento do mundo para o ser só pode suceder pelo caminho do redespertar da ontologia do marxismo" (p.68).

O método de análise inaugurado por Karl Marx se apresenta, segundo Lukács, como o mais completo exercício de compreensão do Ser por considerá-lo em sua materialidade, historicidade, dinamicidade e totalidade. Denominado "método dialético", parte do pressuposto de que "o absoluto e o relativo formam uma unidade indestrutível [e que] a verdade possui seus próprios elementos relativos, ligados ao tempo, ao lugar e às circunstâncias” (LUKÁCS, 1997, p.82). Desprezando qualquer concepção metafísica do mundo, estabelece que o critério último do ser ou não-ser de um fenômeno é a realidade social, e que a única ciência capaz de compreender os fenômenos em suas múltiplas funções é a história, por compreendê-los em sua processualidade, circunstacialidade e totalidade.

Lukács diz que, segundo Marx e Engels,

só existe uma ciência unitária: a ciência da história, que concebe a evolução da natureza, da sociedade, do pensamento, etc., como um processo histórico único, procurando descobrir deste processo as leis gerais e as leis particulares (LUKÁCS, 1997, P.82).

Nessa perspectiva, o Ser só pode ser compreendido à luz da totalidade e em sua historicidade. O conhecimento é possível somente partindo-se da compreensão dialética da realidade, fruto da ação humana na história. Para conhecer, potencializar e modificar sua essência, o homem precisa se 
reconhecer como gênero em processo histórico de construção de sua humanidade.

Segundo Lukács (2010), mesmo o marxismo, em algumas de suas expressões, produziu teorias que não captaram a dimensão ontológica da obra de Marx e cometeram erros interpretativos importantes: Por um lado, na perspectiva determinista de Lênin, consideraram como absoluta a noção de lei histórica e os indivíduos como simples agentes passivos; por outro, num viés hegeliano, conceberam a história como produto exclusivo das intenções da vontade humana. Assim, não houve, segundo ele, uma teoria que compreendesse o lugar do sujeito no marxismo, sem subdimensiona-lo ou elevá-lo acima da materialidade que o encerra.

Para Lessa (2007, p.178), Lukács, assim como Gramsci, se situam na corrente denominada de marxismo ontológico. Tal corrente,

ao mesmo tempo em que reafirma o caráter comunista da obra marxiana, volta-se a demonstrar que o seu caráter revolucionário também está em conceber o mundo dos homens enquanto uma nova forma de ser, uma nova materialidade, que se consubstanciaria pela construção teleologicamente posta de uma nova objetividade. A dialeticidade e o materialismo da obra marxiana seriam assim completamente reafirmados mediante a postulação da absoluta (pois ontológica) sociabilidade e historicidade da substância social.

Desse modo, Lukács faz parte de uma corrente que recupera as discussões ontológicas na problemática de se pensar o ser humano, e o faz em bases materialistas, valorizando e enfatizando, no pensamento de Marx, o lugar do sujeito, dimensão pouco explorada ou até mesmo subdimensionada em outras vertentes do marxismo ${ }^{4}$. Encontrou, em Marx, a possibilidade de determinar a essência e a especificidade do Ser social, considerado a mais elaborada manifestação do Ser. Dessa forma, transformou sua obra em uma grande tentativa de desvendar o estatuto ontológico da obra de Marx.

\footnotetext{
${ }^{4}$ Aqui se faz referência, principalmente, às apropriações feitas do pensamento de Marx pelos teóricos da Revolução Russa, para quem o homem não foi suficientemente considerado em sua subjetividade e potencialidade individual.
} 
Para ele, a ontologia de Marx é "uma ontologia materialista da natureza, que compreende em si a historicidade e a processualidade, a contraditoriedade dialética, etc” (LUKÁCS, 1979, p.20). É uma cientificidade que não perde jamais a ligação com a atitude ontologicamente espontânea da vida cotidiana; ao contrário, o que faz é depurá-la, desvendála continuamente a nível crítico, elaborando conscientemente as determinações ontológicas que estão necessariamente na base de qualquer ciência.

Para Lessa (2007, p.13), “A ontologia lukacsiana tem por objetivo demonstrar a possibilidade da emancipação humana, da superação da barbárie da exploração do homem pelo homem”. O potencial emancipatório dessa ontologia reside no fato de considerar o lugar comum dos homens - a vida cotidiana - como o ponto de partida da compreensão do ser em suas manifestações.

O lugar da compreensão do ser não pode ser outro que a vida cotidiana, que o acontecimento em sua materialidade e historicidade. A apreensão das manifestações do Ser na vida cotidiana não pode ser dar de forma imediatista ou isolada.

O modo de consideração ontológico tem de [...] sentir-se capaz de submeter a uma crítica fundada no ser mesmo as manifestações mais elaboradas do ser social, precisa mobilizar constantemente esse método crítico também em relação à vida cotidiana (LUKÁCS, 2010, p.69).

Se a ontologia havia sido praticamente descartada na modernidade, Lukács a recupera não como um retrocesso às questões medievais, mas como tentativa de recuperar o humano que foi reduzido a mercadoria pelo capitalismo.

A ontologia lukacsiana apresenta três níveis de Ser: O ser inorgânico (tudo o que existe e não possui vida); o ser orgânico (vegetais e animais) e o ser social (humanidade). Apresenta-os como interdependentes:

Sem o ser inorgânico não há vida, e sem a vida não há o ser social: o universo, que é o ser em sua máxima universalidade, é 
uma totalidade composta por distintos processos que, de uma forma ou de outra, são articulados entre si (LESSA, 2007, p.85).

O ser humano é naturalmente orgânico, mas, em sociedade, desenvolve-se e opera aquilo que Lukács (1979) denomina de salto ontológico, produzindo o ser social. Esse nível de ser se desenvolve a medida em que a humanidade faz recuarem as determinações do nível orgânico postas pelas barreiras naturais. Humanizando-se ou civilizando-se, o homem se constitui social e diminui os limites impostos pela animalidade.

Para Lukács, é pelo trabalho que o ser humano opera o salto ontológico e ascende do nível orgânico ao social. Ao tentar entender o mundo e, nele, construir condições favoráveis à sua existência, o homem lança mão do trabalho e por meio dele modifica o mundo ao mesmo tempo em que transforma a si mesmo. A vida humana não seria possível sem o trabalho, que

é uma condição da existência do homem, independentemente de todas as formas de sociedade; é uma necessidade natural eterna que tem a função de mediatizar o intercâmbio orgânico entre homem e natureza, ou seja, a vida dos homens (LUKÁCS, 1979, p. 99).

É no trabalho que se dá a relação do ser humano com a natureza, e é pelo trabalho que o homem se afasta das determinações naturais (orgânicas) e se constrói como Ser Social. “O homem se fez homem diferenciando-se do animal através do seu próprio trabalho” (LUKÁCS, 1997, p.84).

Concebido dessa forma, o trabalho pode ser considerado o fundamento de toda atividade humano-social. "O trabalho é a forma inicial do relacionamento entre o homem e o mundo e a base das diferentes formas de consciência, de reflexo, daí advindas” (FREDERICO, 1997, p.56).

A transformação do ser humano e da natureza pelo trabalho se dá de forma dialética. O desafio da existência ante as adversidades naturais impõe ao homem a necessidade de planejar suas ações e agir segundo esse plano. A esse planejamento consciente das ações Lukács (1979) denomina "pôr 
teleológico"5. A ele se segue a ação transformadora pelo trabalho. O resultado dessa ação, que nem sempre corresponde ao seu planejamento, leva o homem a refletir e melhorar sua consciência do mundo, bem como a planejar ações posteriores com maior grau de certeza, o que leva a atos de trabalho melhor elaborados, e assim sucessivamente.

Em suma, o pôr teleológico, para Lukács (1979), garante que no final do processo emerge um trabalho que estava presente desde o início, de forma ideal;

Para o autor, o salto que o ser humano dá quando faz recuar as barreiras naturais e passa da dimensão orgânica para a social, se dá muito mais em função da reflexão que o trabalho proporciona em relação ao pôr teleológico anterior, do que às transformações materiais produzidas pelo ato do trabalho em si. A reflexão surgida da comparação entre os resultados e os objetivos iniciais do trabalho humaniza e transforma o homem em ser social muito mais do que a materialidade da qual emergiu.

Os atos de consciência humanos se externalizam e materializam pelo trabalho. A esse fenômeno Lukács (2010) denomina “exteriorização”. Por ele, o ser humano não só cria, conscientemente, um novo ser, como cria a si mesmo como ente humano genérico.

A natureza - nível orgânico do ser - opera por causalidade, de forma natural, sem determinismos ou destinos. Os homens - nível social do ser atuam com ideações prévias, com pores teleológicos cuja finalidade foi por eles previamente estabelecida. O trabalho une estes dois níveis ontológicos e

realiza a unidade sujeito-objeto e, ao mesmo tempo, aponta para a [...] relação entre 'causalidade' (o conhecimento dos nexos da realidade material) e 'teleologia' (a pré-ideação, os projetos concebidos pela consciência), que passa a determinar concretamente o campo possível da liberdade humana” (FREDERICO, 1997, p.27).

\footnotetext{
${ }^{5} \mathrm{O}$ "pôr teleológico" é um dos conceitos centrais da obra de Lukács. Deriva de telos (do grego, fim; finalidade) e pode ser explicado como uma finalidade previamente estabelecida pelo indivíduo que, por meio do ato de trabalho, visa alcançá-la. Em outras palavras, é um fim posto inicialmente ao trabalho.
} 
É o trabalho que inaugura a relação sujeito/objeto, separando o homem da natureza e fazendo-o um sujeito ativo. Os atos de trabalho remetem o ser social à criação de necessidades e ao desenvolvimento de meios para sua satisfação, propiciando o surgimento de uma "consciência de si próprio que, com o desenvolvimento da sociabilidade, exerce um papel cada vez mais notável no seu desenvolvimento” (LESSA, 2007, p.91).

Não somente o sujeito se estabelece em oposição ao objeto no e pelo trabalho, mas também nele e por ele ocorre a passagem entre o indivíduo e a totalidade, o conhecimento da natureza e da sociedade e a atuação transformadora do mundo em benefício do homem;

As ações individuais, os pores teleológicos particulares e as subjetividades externalizadas pelo trabalho acabam por constituir um universo complexos de relações, que se dá no ser social, na coletividade. A soma dos atos de trabalho dá o curso da história da humanidade. O indivíduo, ao idealizar previamente sua ação e agir segundo esse ideal, contribui com o curso da história. Assim, “O ser social é muito mais que uma mera totalidade: é uma universalidade potencialmente capaz de conscientemente dirigir sua história” (LESSA, 2007, p.91).

Contudo, a divisão moderna do trabalho, por retirar do trabalhador a capacidade de idealizar previamente sua ação - tornando-o um repetidor de atividades mecânicas e sem sentido no processo de realização pessoal conduz a personalidade humana aos modelos mais primitivos de relação com o mundo, criando no humano um desenvolvimento meramente ligado à sua particularidade imediata, para não dizer à sua animalidade. Isso impede que o trabalho eleve o ser humano ao nível de consciência necessário à construção de sua subjetividade, de sua emancipação.

A transformação capitalista do trabalho em mercadoria que se compra e direciona para fins externos às necessidades dos trabalhadores não só impõe resistências à emancipação dos indivíduos, como acaba por transformá-los também em mercadoria e em bens de consumo. 
Reconhecer-se historicamente nesse processo é tarefa fundamental à emancipação dos indivíduos. Por isso, para Lukács (1979), e emancipação só pode partir da compreensão do ser social e das ações humanas realizadas no decurso da história da humanidade, no universo de sua materialidade, por meio do método dialético.

Se a essência humana é a história dos homens (Lessa, 1997, p.92), tomar consciência dela e compreender seus limites e potencialidades é fundamental à emancipação. Emancipar o homem seria, nessa perspectiva, dar-lhe condições de, conscientemente, utilizar-se do trabalho e das finalidades nele implícitas para que seja elevado ontologicamente ao nível social do ser. Dessa forma, a ontologia lukacsiana postula que a ascensão do ser humano do nível orgânico ao social só pode se dar de forma consciente e emancipada.

Abandonando as concepções idealistas que compreendem a essência humana no âmbito da espiritualidade, o indivíduo emancipado percebe-se como ser histórico, cuja essência é social e se constrói pelo trabalho. Em outras palavras, percebe-se como ser que não está dividido em corpo e alma, mas que possui um corpo que, nos limites de sua materialidade, trabalha e transforma o mundo ao mesmo tempo em que constrói a subjetividade necessária à sua participação no nível ontológico mais elevado, o nível do ser social.

É justamente na consciência do corpo próprio que age e desenvolve a essência humana ao mesmo tempo em que se relaciona com o outro que se desenvolve a sexualidade, conforme será demonstrado na sequência do texto.

\section{O espaço da individualidade no ser social}

Os atos de trabalho, que são o meio do ser humano externalizar sua consciência do mundo e imprimir nele sua marca individual, transformam objetivamente o mundo e criam novos objetos ao mesmo tempo em que transformam a consciência humana. Ao criar um novo objeto pelo trabalho, 
o homem se reconhece como sujeito, dando início a um processo pelo qual seus planos, suas ideações prévias, seus pores teleológicos vão se materializando no mundo exterior.

O único lugar onde há alguma teleologia, alguma determinação prévia, é no ato de trabalho, restrito ao âmbito da individualidade ${ }^{6}$. Na natureza, segundo Lukács (1979), não há determinismo. Na história da humanidade também não. É o conjunto das ações subjetivas que dão curso às transformações históricas do ser social, que não segue alguma direção prévia, e sua história também não pode ser revertida. Assim, somente o indivíduo pode fazer uso de ações conscientes e previsíveis para, socialmente, intervir no curso da história da humanidade.

Recuperar e enfatizar o lugar do indivíduo - enquanto subjetividade como agente da transformação social, talvez seja a maior contribuição de Lukács à compreensão das bases ontológicas da obra de Marx.

Lessa (2007, p.186-187) aponta que um dos principais intentos do filósofo húngaro foi “explicitar as mediações sociais que fazem do homem o único demiurgo de seu próprio destino, de tal modo a demonstrar a possibilidade ontológica da revolução comunista”.

Além de recuperar o conceito de ontologia praticamente esquecido pela tradição filosófica ocidental, Lukács recupera também a concepção de essência humana. A forma como se compreende o que é essencialmente humano é fundamental a qualquer projeto educacional, bem como interfere diretamente em tomada de posições frente à realidade.

Lessa (2007) esclarece que, há dois grandes períodos históricos que demarcam as concepções de essência humana: dos gregos a Hegel; e de Marx até nossos dias.

O que caracteriza [o] primeiro período é a concepção dualista/transcendental de que teríamos um 'verdadeiro ser',

\footnotetext{
${ }^{6}$ Para efeitos didáticos, o ser humano, entendido em sua particularidade, será qualificado, quando concebido em relação à sociedade, como indivíduo/individualidade. Quando em relação à natureza, será qualificado de duas formas: singular/singularidade, (em relação de alienação com o trabalho); sujeito/subjetividade (em relação emancipada).
} 
que corresponderia à essência, à eternidade, ao fixo; um ser menor, uma manifestação corrompida do ser, que seria a espera do efêmero, do histórico, do processual (p.189).

Essa concepção dualista, que opõe espírito e matéria, opõe também corpo e alma ou corpo e mente e dá primazia para a segunda em detrimento da primeira. A sexualidade, enquanto estreitamente ligada à corporeidade, é uma dimensão do homem para a qual não se deu importância, ou melhor, à qual se relacionou toda a sorte de males e pecados na tradição filosófica greco-cristã.

No mundo Grego “existiria uma dimensão essencial, eterna, que não poderia ser construto dos homens nem poderia ser por eles alterada” (LESSA, 2007, p.189). No medievo, mantém-se uma estrutura ideológica dualista:

Deus, enquanto eterna e imutável essência de tudo versus o mundo dos homens, cuja característica é ser o lócus do pecado e, por isso, efêmero, mutável e transitório. Tal como os gregos, os homens medievais também concebiam a sua História como algo imposto a eles por forças que jamais poderiam controlar. Diferente dos gregos, contudo, a concepção cristã pressupõe os homens como essencialmente maus, pecadores e, por isso, merecedores do sofrimento humano. A passagem do mundo medieval ao mundo moderno não conseguiu romper completamente com a dualidade entre a eternidade da essência e a historicidade do mundo dos homens. Certamente o pensamento moderno abandona a concepção medieval de uma essência divina dos homens, a essência humana é agora entendida com a 'natureza' dos homens. Essa natureza nada mais é que a projeção à universalidade da 'natureza específica' do homem burguês; acima de tudo, ser proprietário privado. (LESSA, 2007, p.191).

Em outras palavras, por mais que se afirme que a modernidade tenha rompido drasticamente com a visão de mundo da Idade Média, o fundamento ontológico segundo o qual os homens desdobram na sua história determinações essenciais - que nem são frutos de sua ação, nem poderiam ser alteradas pela sua atividade - continua como no período histórico anterior. Houve apenas a substituição da crença na vontade divina pela crença na determinação da natureza. 
Houve também a crença de que o homem é essencialmente burguês: "Não há como se superar a sociabilidade burguesa porque o homem, sendo essencialmente um egoísta e proprietário privado, não conseguiria desdobrar nenhuma relação social que superasse essa dimensão mesquinha” (LESSA, 2007, p.192).

Assim, até Hegel, a filosofia concebeu a essência humana como fixa, independente, não corpórea, fundante e determinante das transformações históricas, mas nunca atingível ou alterável por elas.

Marx concebe a essência humana como algo dinâmico, social e historicamente construído a partir da subjetividade que nasce e se alimenta dos atos de trabalho. Tal concepção abre possibilidades de pensar o indivíduo numa dimensão de responsabilidade e de não omissão ante a condução dos destinos da humanidade. Assim, mais do que em outras teorias, a subjetividade - enquanto consciência histórica do homem e direcionamento de suas ações na coletividade - ganha peso e exerce papel central na ontologia de Marx segundo o pensamento de Lukács.

Longe de considerá-la simples decorrência das relações materiais, Lukács, na esteira de Marx, delineia com precisão o papel ativo da consciência na construção do mundo dos homens. A consciência não é apenas imprescindível ao trabalho [...] mas ainda efetua a mediação entre a individuação e a sociabilidade. Sem a ativa participação da consciência, não apenas a prévia-ideação, mas até mesmo a reprodução social não seriam possíveis (LESSA, 2007, p.120-121).

Nesse sentido, o indivíduo, enquanto consciência que teleologicamente põe finalidades à sua ação, aos seus atos de trabalho, passa a ser entendido como uma subjetividade que alimenta o desenvolvimento do ser social e dá rumo à história. O movimento objetivo do Ser Social é fruto dos atos individuais dos sujeitos que respondem conscientemente às demandas sociais, em permanente movimento dialético e irreversível.

Todo ato singular alternativo contém em si uma série de determinações gerais que, depois da ação que delas ocorre, tem efeitos ulteriores (independentes das intenções conscientes), ou seja, produzem outras alternativas de estrutura análoga e fazem 
surgir séries causais cuja legalidade termina por ir além das intenções contidas nas alternativas (LUKÁCS, 1979, p.84).

Em outras palavras, os atos de trabalho dos sujeitos, cuja intencionalidade é previamente definida e cujos resultados podem ser imediatamente percebidos, quando diluídos na totalidade do Ser Social podem ganhar dimensões que transcendem as finalidades postas individualmente. São estes atos que, somados aos atos particulares de todos os indivíduos, compõem e põe em movimento a história da humanidade que é a historia do Ser Social.

Ao enfatizar a importância do sujeito na teoria lukacsiana, não se quer propor que ele aja de forma independente ou completamente livre das determinações materiais de sua existência. Isso porque os atos particulares de trabalho não são de todo puros, ou livres de determinações sociais. As circunstâncias histórica e socialmente postas determinam, em alguma medida, as possibilidades de escolha dos indivíduos. Para Lessa (2007, p.108), "não há nenhum tipo de subjetividade que não seja social nas suas raízes e determinações mais profundas".

A relação entre indivíduo e sociedade é dialética. Tanto os atos individuais são realizados partindo-se de circunstâncias socialmente postas, como o decurso da história da humanidade é determinado pelo conjunto das ações individuais. Segundo Lukács (2010, p.96) “modos de reagir dos homens típicos da vida cotidiana podem influenciar decisivamente, ou pelo menos parcialmente, em termos positivos ou negativos, suas objetivações mais elevadas em sentido social”.

Para ele, é correto que

tanto as tarefas socialmente relevantes só [podem] ser convertidas em ser por decisões alternativas dos indivíduos, quanto que nenhuma decisão alternativa pessoal possa ocorrer sem ser socialmente determinada em seus traços decisivos (p. 96).

Em suma, os indivíduos tem participação decisiva no ser social, mesmo que em circunstancias e condições dadas. Porém as possibilidades 
de participação consciente no fazer da história do ser social pressupõem que os atos de trabalho sejam também conscientes, não alienados, previamente idealizados com objetivos claros, cujos resultados implicam na objetivação/exteriorização do indivíduo que se emancipa ao mesmo tempo em que transforma a natureza em seu proveito e da humanidade.

Contudo, no modo de produção capitalista, tais possibilidades são reduzidas ou bloqueadas, de forma que o resultado do trabalho tende a implicar na alienação, pois

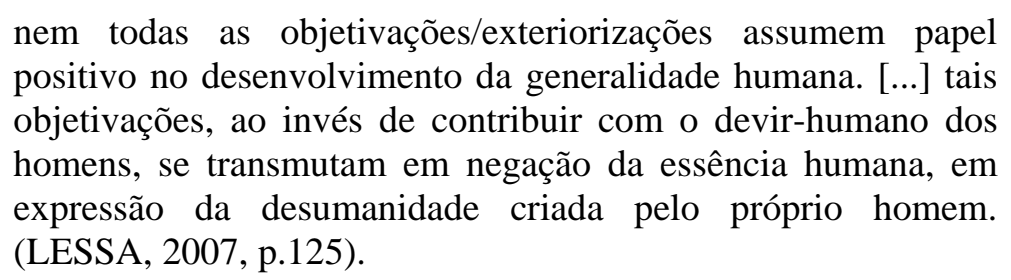

Para Lukács, o capitalismo é uma formação social que cria um patamar de potencialidades para a realização da subjetividade jamais conseguida por outras, ao disseminar que a consciência de que o homem é o único senhor do seu destino. Contudo “a plena realização dessas potencialidades [...] requer a superação das alienações que predominam na sociabilidade contemporânea, as quais têm no processo de acumulação de capital o seu fundamento ontológico último” (LESSA, 2007, p.154).

O trabalho é alienado quando é negado ao trabalhador a possibilidade de decidir conscientemente sobre sua ação, quando o pôr teleológico lhe é imposto e ocultado, quando seu esforço físico é empregado para realizar objetivos que lhe são estranhos e quando o fruto do que produz serve para benefício de outrem.

Alienação e consciência se opõem. Quanto maior a primeira, menor será a segunda e, consequentemente, menor será a possibilidade do indivíduo participar ativamente na condução da história da humanidade e na transformação do ser social em seu benefício.

É no bojo da exploração capitalista do trabalho humano que ocorrem dois fenômenos característicos da alienação: a fetichização e a reificação. 
Estes conceitos importantes da análise de Marx são por Lukács (1979) retomados e classificados como cópias imperfeitas de uma realidade incompreendida. A primeira ocorre quando o produto do trabalho humano a mercadoria - ganha, pela ideologia, uma dimensão transcendente e é assumida pelos indivíduos como algo essencialmente necessário, como finalidade da existência humana, desconsiderando-se seu aspecto de simples bem material que é um meio de subsistência e não um fim em si mesmo. Na fetichização, “os resultados dos atos singulares realizados pelos homens assumem, para os seus próprios agentes, a forma fenomênica de um destino transcendente” (LUKÁCS, 1979, p.51).

Já na reificação, ocorre o contrário: o ser humano perde, por meio da ideologia, a compreensão de sua essência, e passa a ser considerado uma mercadoria, um bem de consumo. Seu trabalho - único elemento de emancipação e tomada de consciência do mundo - também passa a ser comercializado em troca de salários. Segundo Frederico (1997, p.33), a reificação é uma conseqüência do fetichismo da mercadoria, que faz com que os humanos se relacionem entre si "como portadores de mercadorias, como personificação das categorias econômicas”.

A recuperação do individuo como ser que constrói a si mesmo e se dignifica, pelo trabalho, se coloca como tarefa necessária na mesma medida e proporção em que o poder das ideologias cresce e aumenta a alienação das pessoas.

Lukács (2010, p.316) afirma que o ser humano nasce singular, mas não indivíduo. A individualidade vai substituindo a singularidade ao mesmo tempo em que o social supera o biológico. Quando o trabalho é alienado, a tendência do ser humano é permanecer ou retornar à singularidade, perdendo o potencial transformador de sua ação que, nesse caso, é dissociada da reflexão.

Em tempo de presença forte de ideologias alienantes, é um grande desafio para o indivíduo garantir sua subjetividade e superar a mera 
singularidade. Isso só pode nascer de uma consciência histórica de si mesmo, enquanto produto e produtor do ser social. Segundo Lukács,

O ser humano, até em seu autoconhecimento tão rodeado de lendas, deve reduzir-se ao ser-em-si de sua própria constituição categorial e comprová-la por meio de sua própria práxis, se quiser realmente conhecer a si próprio (2010, p.381).

A individualidade se constrói no processo de socialização. Não basta compreender isoladamente o ser humano para ter-se um indivíduo. A singularidade se transforma em individualidade por um processo de tomada de consciência histórica. Somente na escolha consciente de si mesmo no mundo, no pôr teleológico característico dos atos de trabalho conscientes, no momento em que o sujeito toma para si algo como objeto de análise é que se estabelece uma subjetividade.

Assim, para Lukács (2010, p.225), a individuação é resultado da sociabilidade, é a concretização do ser no exemplar singular. A personalidade humana se constrói partindo-se do "recuo das barreiras naturais”, no confronto da pessoa com a sociedade.

Para o autor, o ser humano singular é o "ser em si". Para que se transforme em subjetividade, ou seja, em "ser para si”, necessita de um pôr teleológico de qualidade superior que apenas pode ser objetivado pelo "homem que é capaz de elevar-se com a consciência para além da própria particularidade" (p. 240).

Diferentemente das espécies animais, os indivíduos não são exemplares mudos ${ }^{7}$, isto porque participam ativamente, com suas ações, no destino da totalidade do gênero humano. Segundo Lessa (2007, p.111), “a substância de cada indivíduo é dada pela direção e pelo tipo das relações que o indivíduo estabelece com o mundo”.

\footnotetext{
${ }^{7}$ Para Lukács, ao alcançar o nível ontológico de ser social, o ser humano supera o mutismo. São mudos os seres orgânicos e inorgânicos, ou seja, aqueles que são incapazes "de se elevar à consciência do seu em-si [...] numa incessante reprodução do mesmo" (LESSA, 2007, p.24).
} 
A individualidade só se constrói mediante a gestão consciente da tensão indivíduo/gênero. O ser humano é sujeito que se relaciona com os objetos do conhecimento, e indivíduo que se relaciona com o próprio gênero. A subjetividade surgida na primeira relação se externaliza na segunda. É este o espaço das relações sociais, do ser-com-o-outro, do ser que, pela corporeidade, age no mundo e se relaciona.

\section{A sexualidade e a individualidade}

A dimensão sexual tem sido um importante viés explorado pelo capitalismo no exercício de fetichizar e reificar os indivíduos. A fetichização é visível quando o ato sexual e todos os produtos industrializados que a ele se destinam se tornam uma finalidade e não um meio de realização humana; quando ganham uma dimensão que transcende sua função. A reificação se dá no momento em que as relações sexuais são banalizadas e as ideologias impõem um modelo quantitativo como rito a ser seguido pelos indivíduos. Dessa forma, os próprios seres humanos assumem uma condição de objeto sexual.

Para Nunes (2005, p.29) ao mesmo tempo em que o capitalismo dilacera as vidas e as relações sociais, afirma o discurso da sexualidade como uma tábua de salvação, cooptado para “a construção de uma metodologia infalível de consumo e alienação”. Nesse modelo econômico, o sexo é aproveitado de forma lucrativa. Ao se pregar a libertação sexual dos indivíduos, instiga-se o consumo sem limites, abrindo um mercado de exploração e controle eficiente, cuja matéria prima - o desejo - jamais se extingue.

Por trás do discurso da liberação, há uma poderosa forma exploração e de repressão. Estimulam-se as práticas sexuais e o consumo dos produtos a elas direcionados, mas nega-se à sexualidade o desenvolvimento emancipado e central na construção da subjetividade, enquanto dimensão ligada à corporeidade e fundamental no estabelecimento das relações com as pessoas (individualidade) e com o mundo (subjetividade). Tais relações se 
dão por meio do corpo que apreende o objeto e se relaciona com outros. Por isso a centralidade da corporeidade e, por extensão, da sexualidade enquanto dimensão culturalmente construída que dá significado humano a essas relações.

Historicamente, no Ocidente, foram construídos conceitos contraditórios sobre sexualidade. Num momento (era cristã), desprezava-se o corpo e impunha-se o "dever silenciar" da sexualidade em nome do pecado, o que se configurava uma repressão em sentido de negação. Em outro momento (a partir do séc. XIX), valoriza-se o corpo como meio e força produtiva, impondo-se o “dever falar” da sexualidade, em nome da liberação, o que, de forma afirmativa, também se configura uma repressão, pois não deixa de ser um imperativo. Às consciências dos indivíduos restou um misto de interdição moral com afirmação social ${ }^{8}$.

Pensar a sexualidade em perspectiva emancipatória, como subsídio teórico de uma prática educacional, requer, inicialmente, a compreensão das formas como foi concebida na história da humanidade, bem como os resquícios dessas concepções na compreensão atual dos indivíduos sobre seu corpo e suas relações.

Uma compreensão histórica e crítica da sexualidade deve buscar, segundo Nunes (2006, p.71), “identificar os estereótipos sexuais e questionar seus fundamentos e representações”, ou seja, mostrar como os discursos sobre sexualidade foram construídos para que possam ser desconstruídos deixem no indivíduo o espaço da possibilidade da emancipação ${ }^{9}$.

Contudo, a proposta deste estudo se volta para a necessidade de demonstrar a centralidade que essa dimensão exerce na construção da subjetividade, e para isso a ontologia lukacsiana pode servir de referencial importante.

\footnotetext{
${ }^{8}$ Cf. FOUCAULT, 2004.

${ }^{9}$ Não é objetivo deste texto apresentar um estudo histórico da sexualidade. Apenas fez-se menção a essa necessidade, que foge às pretensões desse estudo e fica para outro momento.
} 
Concorda-se com Nunes (2005, p.117) que

o lugar do homem é a corporeidade e a dimensão antropológica primeira é o corpo. É o corpo o lugar híbrido da natureza e da cultura. Por isso nos interessa recuperar uma significação mais digna, lúdica, livre para o corpo” (NUNES, 2005, p.117).

A natureza primeira do ser humano situa-se no nível orgânico do ser. A cultura situa-se no nível social do ser. O corpo, lugar da sexualidade, está marcado por esses dois níveis e é, por assim dizer, a ligação entre ambos. Isto significa que corpo e a sexualidade são compostos ou participam de duas realidades: o primeiro em relação à natureza e a cultura e a segunda em relação à sociedade e o indivíduo. Assim, a autêntica sexualidade deve partir da vivência autônoma da corporeidade do indivíduo, nesse construir-se humano com a natureza, com a cultura, com a sociedade e consigo mesmo por meio do trabalho e do fazer-se sujeito. Em outras palavras, é pela sexualidade que o ser humano se relaciona com os outros e, por extensão, consigo mesmo. Ela é a ponte, estabelecida entre o indivíduo e a sociedade, que possibilita o ir e vir dialético da construção da personalidade; é o “lugar” da relação que, nos atos de trabalho, constrói a subjetividade.

Lukács não dedica especial atenção à sexualidade em seus estudos ontológicos. Em raros momentos faz menção a ela, sem se deter ou aprofundar o entendimento. Mas, ao apontar como se dá a construção da subjetividade, dá margem para a compreensão da centralidade da corporeidade. Segundo ele, mesmo sendo profundamente radicada no biológico, assim como a nutrição, a sexualidade não permanece fechada nessa esfera (a biológica), mas se coloca ante o sujeito como possibilidade de escolha que tem o poder de modificá-lo.

Diferentemente dos animais, que possuem apenas o sexo, e para quem as transformações internas não ocorrem por opção, mas sempre em nível puramente biológico, a sexualidade humana pressupõe, mesmo que ligada ao biológico, um recuo das barreiras naturais.

Lukács (1979, p.145) afirma que o gênero humano só se realiza superando o mutismo natural, diferentemente de outros gêneros: 
a genericidade universal biológico-natural do homem, que existe em si, só se pode realizar como gênero humano na medida em que os complexos sociais existentes [...] façam sempre com que o mutismo da essência genérica seja superado pelos membros de tal sociedade, uma superação que os torne conscientes [...] da sua generidade enquanto membros desse complexo.

O sexo representa uma dimensão muda, de nível orgânico. A sexualidade está na passagem desse nível à dimensão não mais muda, do ser social. O indivíduo que, subjetiva e eticamente, faz escolhas conscientes a partir de seus atos de trabalho, tem na corporeidade e na sexualidade um importante meio de significar ou orientar tais escolhas. Disso decorre que a superação do mutismo implica no reconhecimento histórico e material de si mesmo, reconhecimento que passa pela consciência das relações que se situam no âmbito da sexualidade.

Sigmund Freud (2006) foi quem melhor demonstrou a importância da sexualidade na construção da subjetividade e das relações sociais. O indivíduo bloqueado ou reprimido sexualmente, frequentemente apresenta dificuldades de construir sua compreensão da realidade, visto que há, igualmente, dificuldades de constituir suas relações com a natureza e com os outros. Para ele (p.162), as neuroses desenvolvidas na fase adulta têm relação direta com a repressão sexual ocorrida na infância. Ele afirma que “os neuróticos preservam o estado infantil de sua sexualidade ou foram retransportados para ele”. Assim sendo, a qualidade das relações fundamentais à emancipação do indivíduo, depende da vivência e da construção social da sexualidade.

Segundo Lukács (2010), Freud se equivoca ao considerar o homem somente como biológico, e ao separar matéria de espírito. Para ele, “não há divisão nem clivagem no homem” (p.43). Considera que o excesso da psicanálise se dá quando concebe a vida espiritual como determinante da vida biológica do ser. 
Em outras palavras, Freud percebe a importância da sexualidade na formação da subjetividade, mas a compreende de forma isolada, separada da materialidade, embora determinante na vida do indivíduo.

Ao conceber o indivíduo como dependente do ser orgânico, Lukács dá possibilidades de se compreender ontologicamente o corpo, coisa que a tradição filosófica ocidental não fazia. Contudo essa dependência não é concebida exageradamente, como ocorre com o positivismo, que faz uma transposição simplista da natureza para o domínio social (darwinismo social).

As formas de objetividade do ser social se desenvolvem, à medida que surge e se explicita a práxis social, a partir do ser natural, tornando-se cada vez mais claramente sociais. (...) a transformação de um ser-em-si num ser-para-si. (LUKÁCS, 1979, p.18)

É, portanto, a partir desta relação dialética entre corpo orgânico e inorgânico que podemos compreender o estatuto ontológico proposto por Marx e desenvolvido por Lukács, no qual a corporeidade pode ser pensada.

A sexualidade é uma função que aparece sempre naturalmente fundada, mas se sociabiliza no decurso da humanidade. "O homem nunca é, de um lado, essência humana, social, e de outro, pertencente à natureza; sua humanização, sua sociabilização não significa uma clivagem de seu ser em espírito (alma) e corpo” (Lukács, 2010, p.42).

É importante frisar que, no desenvolvimento do ser social, as barreiras naturais não desaparecem. Apenas recuam. Portando, o desenvolvimento emancipado da sexualidade é de fundamental importância para que a marca natural do sexo não seja canalizada para fins alienantes.

Para Lukács (2010, p.252), tanto a sexualidade como a alimentação são necessidades humanas em que o biológico não pode ser totalmente ultrapassado, mas que estão cada vez mais e intensamente repassadas por motivos sociais. 
A consciência do ser “em si”, orgânico, é fundamental para a evolução do ser social e do ser "para si”. Compreender-se corporalmente é indispensável ao constituir-se sujeito. A compreensão do corpo e da sexualidade como dimensões que estabelecem relações objetivas e sociais é essencial para qualquer processo educativo que pretenda desenvolver a subjetividade e promover a emancipação do ser humano.

\section{Considerações finais}

Considerações sobre a sexualidade não podem ser depreendidas diretamente da obra de Lukács, por não ter sido esse tema objeto específico de análise do autor. Contudo, para que se possa pensá-la em perspectiva emancipatória, os referenciais ontológicos necessários devem compreender a realidade de forma dinâmica, valorizar a materialidade como lugar por excelência onde ocorrem as transformações dessa realidade e afirmar o indivíduo - sem separar corporeidade e espiritualidade - como sujeito de tais transformações. O pensamento ontológico de György Lukács é fundamental nesse sentido.

Sua concepção de ontologia, que mostra como interdependentes os três níveis de ser - inorgânico, orgânico e social - e reconhece a importância do trabalho - ação material por excelência - na constituição da subjetividade e no desenvolvimento da história da humanidade, abre grande possibilidade de se refletir sobre a sexualidade como dimensão que, mesmo originária de uma pré-disposição biológica, se faz social e exerce grande importância no processo objetivação dos indivíduos no ser social.

Uma educação emancipatória da sexualidade deve ter como seus estes pressupostos ontológicos. Emancipar os indivíduos pela sexualidade não significa orientar ou definir sua vivencia sexual, mas sim tornar as escolhas pessoais conscientes e desfetichizadas. Nesse sentido, os pressupostos ontológicos de Lukács se mostram solo abundante e fértil. 


\section{Referências Bibliográficas}

ARISTÓTELES. Politica. Brasília: Ed. Da UNB, 1985.

BERTRAND, Michele. O homem clivado - a crença e o imaginário. In SILVEIRA, Paulo; DORAY, Bernard (orgs). Elementos para uma teoria marxista da subjetividade. São Paulo: Vértice, Editora Revista dos Tribunais, 1989 (p.15 40).

BLACKBURN, Simon. Dicionário Oxford de filosofia. Rio de Janeiro: Jorge Zahar Ed. 1997.

COSTA, Gilmaísa. Trabalho, individualidade e pessoa humana. Pós-Graduação Serviço Social, UFPE, 2005. (Tese de doutoramento).

FOUCAULT, Michel. Sexualidade e solidão. In: MOTA, Manoel de Barros (org). Foucault: ética, sexualidade, política. Rio de Janeiro: Forense Universitária, 2004.

FREDERICO, Celso. Lukács: um clássico do século XX. São Paulo: Moderna, 1997.

FREUD, Sigmund. Um caso de histeria, três ensaios sobre a sexualidade e outros trabalhos. Rio de Janeiro: Imago, 2006.

LESSA, Sérgio. Para compreender a ontologia de Lukács. 3ed. Ijuí: Editora Unijuí, 2007.

LUKÁCS, Georg. Ensaios sobre literatura. In FREDERICO, Celso. Lukács: um clássico do século XX. São Paulo: Moderna, 1997.

Ontologia do ser social: Os princípios ontológicos fundamentais de Marx.

São Paulo: Livraria Editora Ciências Humanas, 1979.

Prolegômenos para uma ontologia do ser social. São Paulo: Boitempo,

2010.

MARX, Karl. A origem do capital: a acumulação primitiva. São Paulo: Fulgor, 1989.

NUNES, César. Desvendando a sexualidade. 7 ed. Campinas, SP: Papirus, 2005.

2006. . A educação sexual da criança. 2 ed. Campinas, SP: Autores Associados, 